\title{
NICOLÒ VITO DI GOZZE (NIKOLA VITOV GUČETIĆ, 1549-1610) AND THE ROLE OF MUSIC IN RENAISSANCE DUBROVNIK
}

\author{
MONIKA JURIĆ JANJIK
}

\begin{abstract}
Renaissance politician and philosopher Nicolò Vito di Gozze treated music subjects in three among his works: Dialogo della bellezza (Dialogue on Beauty, 1581), Governo della famiglia (The Governing of the Family, 1589) and Dello stato delle republiche (On the State of the Republics, 1591). Although in these works Gozze mentioned music in a number of shorter passages, it is possible to perceive three larger topics he discussed in more detail: musical instruments, musico-theoretical ideas and the functions and effects of music. Gozze's thoughts on music had been mostly influenced by ancient Greek thinkers, Plato and Aristotle, thus Gozze pointed out the importance of role of music in society, especially within the educational system and the process of learning.
\end{abstract}

Key words: Renaissance; Dubrovnik; Nicolò Vito di Gozze.

\section{Introduction}

The Dubrovnik Renaissance intellectuals displayed vivid interest in various areas of culture covering a broad spectrum of topics and themes (e.g. philosophy, pedagogy, politics, ethics, literature, arts etc.) among which they regarded musical issues as highly important. This paper presents thoughts on music by the prominent Dubrovnik intellectual Nicolò Vito di Gozze (the modern Croatian version: Nikola Vitov Gučetić, 1549-1610). Gozze was a man of letters, theologian, philosopher, jurist, politician, pedagogue and a member of the Academy Dei Concordi (in Dubrovnik Croatian dialect: Akademija složnijeh), the learned society in which some of the outstanding Dubrovnik intellectuals gathered to discuss artistic, philosophical and literary issues. Although no direct proofs on musical activities within the Academy have been found yet, it should be assumed with great certainty that music made part of discussions at its gatherings. This claim can be supported by thoughts on music which originate from the works by two of its most important members: the first one is Nicolò Vito di Gozze, who treated music subjects in three among his works: Dialogo della bellezza (Dialogue on Beauty, 1581), Governo della famiglia (The Governing of the Family, 1589) and Dello stato delle republiche (On the State of the Republics, 1591), while the second one is Michele (Miho) Monaldi (1540-1592), Dubrovnik 
poet and philosopher whose work Irene, ovvero della bellezza (Venice, 1599) is considered to be the first aesthetic treatise in Croatia (Tuksar, 2004, 4-8).

Regarding the practical aspects of music production in Renaissance Dubrovnik, the most important activity was exercised by musicians of the Duke's Chapel, formed already as a small group of winds at the very beginning of the $14^{\text {th }}$ century and existing up to the beginning of the 19th century. Throughout the full five centuries, Dubrovnik continuously gave socio-political and financial support to its official city and state music, which could well be considered as a unique phenomenon in the history of Croatian and European music-making. Musicians of the Duke's Chapel were under strict control of the Duke, or the governing body of the Republic called the Small Council, with which they would conclude a one-year contract for their services in the Duke's Chapel. Musicians were primarily at the disposition to the Duke, but also to Dubrovnik population at large, no matter of their social and property status, so everyone could enjoy its aesthetic values during occasional festive performances of sacred music in the Cathedral and St Blasius church. Namely, those performances were financially backed by the State. Beside their obligations in the Duke's Chapel in Dubrovnik, some among its musicians also went abroad, giving guest performances, especially at the neighbouring courts of Bosnia and Herzegovina. Some of the musicians occasionally also performed music outside of official duties, in private arrangements, such as wedding ceremonies, and various other family celebrations. Archival data furnish information on some 20 musicians active in the Chapel during the 16th century, among whom the most important seemed to have been the Franko-Flemish instrumentalists and composers from the Courtoys family: Lambert the Elder (active 1554-1570), his son Henryk (1573-1629), and also later his grandson Lambert the Younger (active 1621-1664) (Demović, 1981, 69-141).

Gozze was held in high esteem by his contemporaries, being elected seven times to the position of Dubrovnik Duke. Thus his ideas on music and culture in general could be considered as widely shared and accepted among the Dubrovnik intellectuals of his time. Gozze spent his entire life in Dubrovnik and many of his ideas on music seem to have been inspired and thus to have originated from his experience of the living music practice of his town. This goes back even to his childhood: he himself reported that he personally participated at an early age in performances of works by Marin Držić (1508-1567), the most famous $16^{\text {th }}$-century Dubrovnik playwright. In his work Dello stato delle republiche Gozze wrote:

"The fact that such music can always comfort our souls ... I myself have experienced at large; because when in my company there were invited to present the most noble acts in comedies and tragedies, in order that my nature be not 
frightened of such scenes I commanded ... to cheerfully play trumpets and other winds; and, furthermore, I had performed this role at my most tender age to the greatest satisfaction of the author himself, Marino Darxa, and the spectators; so that I have, along with treatises, personally experienced enough - as earlier mentioned - in how music is in harmony with our soul." (Gučetić, 2000, 414).

Although Gozze did not specify which play was in question, from this quote it is clear that he actively participated - by playing a wind instrument - in performance of musical number in one of Držić's comedies (Jurić, 2012, 178179).

It is well-known that the forming of ideas among Renaissance thinkers was widely influenced by both Plato and Aristotle, resulting in specific forms of Neo-Platonism and Neo-Aristotelism. Taken generally, it could be stated that Gozze's approach and the methods used manifest a link or even a compound of Neo-Aristotelism and Neo-Platonism. Regarding Gozze's thoughts on music, it is possible to perceive three larger topics he discusses in more detail: musical instruments, musico-theoretical ideas and the functions and effects of music.

\section{1) Musical instruments}

From Gozze's writings on music it can be concluded that he was well acquainted with musical instruments in general. In spite of his general Platonic-Aristotelian orientation in his discussion on instruments he also introduced contemporary elements. In the passages where Gozze discusses musical topics he mostly concentrates on two musical instruments: cithara and lyre. Gozze uses several different Italian terms to denote cithara: citara (Dialogo della bellezza), cetera (Governo della famiglia) and cetra (Dello stato delle republiche), while in Croatian translations of his works only one term is used - citra. However, this term is not appropriate in this context since it is associated to a traditional instrument which is characteristic for Croatian counties of Medimurje and Podravina, thus more appropriate term in the context of Gozze's discussion of instruments would be citara. In Croatian lexicography [e.g. Jakov Mikalja, Blago jezika slovinskoga (Loreto 1649 - Ancona 1651); Ivan Belostenec, Gazophylacium, seu latinoillyricorum onomatum aerarium Gazophylacium illyrico-latinum (Zagreb 1740); Andrija Jambrešić, Lexicon Latinum Interpretatione Illyrica, Germanica, Et Hungarica (Zagreb 1742) (cf. Tuksar, 1992, 235)] the term citara is associated with two meanings: the first one is applied to the kithara from the Antiquity, while the second one is related to the cittern, an instrument from the Modern Age (Tuksar, 1992, 256). It is possible that Gozze under Italian terms citara (Dialogo della bellezza), cetera (Governo della famiglia) and cetra (Dello stato delle republiche) sometimes had in mind the first meaning, and sometimes the second 
one. This second option is plausible especially if we take into consideration the fact that Gozze was aware of the development and progress of musical instruments which happened in the late Renaissance (Munrow, 1976, 22-23). During the Renaissance the cittern was mainly associated to lower classes and has been used in barber's shops to amuse the waiting customers. On the other hand, Vincenzo Galilei wrote that 16th century citterns from Brescia were popular among the nobility and that they possibly represented a revival of the antique kithara (Munrow, 1976, 80-81).

In his work Dialogo della bellezza Gozze made a comparison between cithara and human body in order to illustrate the preliminary process a man has to go through so he could receive beauty. Gozze describes necessity of tuning cithara's strings in order to produce beautiful sound, thus comparing that process with the preparation of a body before receiving beauty:

"...things which do not receive the perfection in the same order are not prepared for that in the same way; thus it is necessary that human body, before it receives beauty, is well prepared in the accordance of four elements, or moods, however we might name them; because never has an un-tuned cithara produced beautiful sound; our soul is also ready to receive the beauty and grace only when it forsakes the concern over body and removes sensuality from itself; just as gold needs to be cleaned from earthly ugliness in order to shine." (Gučetić, 1995, 89).

Later in the same work Gozze once again points out that harmony of cithara's strings is a very important precondition in accomplishment of musical harmony:

"And if we see and realize with intellect that beauty of voices and object of sight consist of certain proportions, or accordance (for without them it is indeed impossible to say that that an object is entirely beautiful), we must imagine that, since the moods within us are similar to the strings of a cithara [citara], the beauty of our body is caused by their temperature, just as the proportion of cithara’s strings causes harmony." (Gučetić, 1995, 109).

In his work Governo della famiglia Gozze put cithara in the context of practical music making in order to emphasise the importance of musical activities in every stage of life:

"In the same way was music, which is so highly recommended by elderly, always necessary to young people, like I already said, for it always had the power of soothing the emotions of our soul and encouraging us to do anything. (...) And Socrates, knowing the power and nobleness of music, despite being sixty years old, was not ashamed to learn at this mature age how to play lyre and cithara and other string instruments [la lira, e la cetera, \& altri stromenti di corda]." (Gučetić, 1998, 255). 
Gozze will repeat this argument in almost identical manner at the end of his work Dello stato delle republiche (1591):

"If Socrates, knowing the power and nobleness of music, at the mature age of sixty years, was not ashamed to learn how to play lyre and cithara and other string instruments [la lira, e la cetera, \& altri stromenti di corda], who in the world would dare to be ashamed of learning this heavenly (to say so) harmony?" (Gučetić, 2000, 417).

The fact that Gozze used the same argument in two of his works underlines the importance he ascribed to the practice of musical activities at old age and also separates him from Plato's opinion according to which the practical music making was exclusively intended for younger generations.

From these quotes it is apparent that Gozze almost regularly associates lyre with cithara. The only time he mentioned lyre separately from cithara was in his elaboration of educational system: "Plato (...) determined (...) that after those efforts [learning - op. M. J. J.] they [children - op. M. J. J.] should learn how to play the lyre [la lira], for comfort of soul and emotions." (Gučetić, 1998, 187). It is clear that Gozze refers to the educational system from the Antiquity in which singing and simultaneously playing the lyre was one of the most important parts.

Gozze considered other instruments exclusively in his work Dello stato delle republiche, thereby showing his inclination towards instrumental music. Given the fact that Gozze was active in the second half of the $16^{\text {th }}$ and the first decade of the $17^{\text {th }}$ century, the period in which intensive development of instrumental music occurred, his attitude is also possible to interpret as his accordance with the latest tendencies in music of his time. In the first classification Gozze divided instruments in two groups: old instruments and modern instruments. In the group of old instruments Gozze included string and wind instruments from the Antiquity and the Middle ages with short description of each of them:

\footnotetext{
"We are not completely acquainted with old instruments [antichi istrumenti], such as fistula, tibia, barbiton, heptagone, organistrum, sambuca [fistole, tibie, barbetti, eptagoni, sinfonie, sambuci], some thought that fistula and tibia [la fistole, e Tibia] were similar to trumpet [una Tromba], or according to Javello (...) like cornamuse [corna Musa], which we usually call fife [Pifaro]; barbiton [la Barbita] is quite unknown instrument, and this scholar thought heptagone [Eptagoni] was a seven-sided instrument with seven strings; he described sambuca [i sambuci] as instrument with two large strings which produced low and loud sound." (Gučetić, 2000, 416).
}

After describing old instruments, Gozze proceeded to modern instruments which were used in the Renaissance, and divided them according to the criteria of their appropriateness to noblemen: 
“...if we adapt to our present-day instruments [gl'istrumenti de i tempi nostri], in comparison to ancient instruments [gl'istrumenti antichi], let us tell you that trumpets, pan-pipes, cornamuse, cornets, flutes, trombones, sordun and similar [instruments] [Trombe, Piferi, Corna Muse, Cornetti, Fiauti, Tromboni, Sordine, \& simili], are not suitable - according to Aristotle - to a nobleman; because, in playing them by inflating, chests become breathless, and owing to the efforts in breathing the face becomes very ugly. If anyone deserved praise for this instruments, it is their inventor, Phineas for fistula [fistola], Apollo for tibia [la tibia], Tyrrhenians for trumpets [le trombe], and according to some Phrygians for tibias [le tibie].” (Gučetić, 2000, 416).

Gozze considered wind instruments (trumpet, cornet, flute, trombone, sordun) to be inappropriate for members of high society. Opposed to wind instruments, Gozze considered string instruments (viol and lute) and keyboard instruments (harpsichord) to be appropriate for noblemen, once more showing that he was well acquainted with the contemporary development of instruments:

“... as distinguished from these, (...), viol, lute and harpsichord [la Viola il Liuto, \& il Grauecimbalo] are considered to be very honourable and pleasant [instruments] for both young and elderly people. Harpsichord [il Grauecimbalo] is more recommended for the elderly than young people, for them are viol and lute [la Viola, \& il Liuto] very suitable for refreshment of the spirit, when they are gracefully used after hard work, singing to their accompaniment a canzone, sonnet, Tuscany stanza or something similar, which mentions Alexander Piccolomini." (Gučetić, 2000, 417).

Gozze's selection of instruments which are suitable for noblemen was probably influenced by Castiglione, since he also in his work The Book of the Courtier (Il libro del cortegiano) emphasised that the best kind of music is the one produced by string and keyboard instruments:

"Beautiful music is (...) singing upon the book surely and after a good sort. But to sing to the lute is much better, because all the sweetness cosisteth in one alone, and a man is much more heedful and understandeth better the feat manner and the air or vein of it when the ears are not busied in hearing any more than one voice... But singing to the lute with the ditty (methink) is more pleasant than the rest, for it addeth to the words such a grace and strength that it is a great wonder. Also all keyboard instruments are full of harmony, because the tunes of them are very perfect, and with ease a man may do many things upon them that fill the mind with the sweetness of music. And a music of a set of viols doth no less delight a man, for it is very sweet and artificial." (Castiglione, 1986, 90-91). 


\title{
2) Musico-theoretical ideas
}

If we compare passages in which Gozze treated musico-theoretical ideas it is obvious that his attention is predominantly dedicated to modes, while he discusses harmony and (especially) rhythm in a far lesser extent. From Gozze's selection of the modes it is obvious that his role model was Aristotel. Namely, in his works Gozze does not mention all modes, but just points out Dorian, Phrygian and Lydian as three chief modes:

\begin{abstract}
"The art of music is divided in three parts [tre parti]; the first one is Phrygian, and it moves our spirit towards rage and vehemence, which encouraged Lacedemonians to take weapons against Cretans, and also Timotheus when he rose against Alexander; that kind of music [à questa specie di Musica] is opposed by another, Lydian, whose singing easily returned from the rage and vehemence those who were infuriated by the first kind; the third one is Dorian, which led and stimulated emotions of a soul to seriousness and modesty, with such efficiency and strength that it was almost impossible and difficult to the ones who heard it to steer their soul towards impure or evil act." (Gučetić, 1995, 115).
\end{abstract}

Gozze describes Phrygian and Lydian as two completely opposite modes and denotes Phrygian mode as the one which excites men, while Lydian has contrary, relaxing effect. Gozze presented Dorian mode as a completely separate category, a central mode which has the highest value, supporting his claim by listing examples from the Greek mythology which illustrate ancient Greek belief in the power of modes concerning their influence on human behaviour, i.e. on human emotions. Gozze also mentioned modes outside the context of their impact on human beings, in his discussion on political philosophy, comparing them to political systems:

"I answer you ... that the city is not going to change because of the change itself, but it will change because of the change of the political system; because of this shift in systems from one to another the city's organization will change too, as also happens with harmonies [nelle armonie] where, if the order of voices changes, the very harmonies change, too. Because of their different systems they bore different names in ancient times: Dorian, Frygian, or some other [hor la dorica, hor la frigia, hor altrimenti]." (Gučetić, 2000, 194).

Gozze took over this idea from Aristotle who in his work Politics listed two main political systems and two kinds of melodies:

"...since certain collectiveness is state/city, and collectiveness of citizens is in the social system, when social system changes its form and becomes different it seems that political system changes too, as well as the city, same as the comic choire is different from the tragic one, although they both consist of the same 
people; in similar way every other collectiveness and accordance is different, if the form of that accordance is different, as we say that the harmony of same sounds is different when it is sometimes Dorian and sometimes Phrygian” (Aristotel, 1992, 1276b1-10).

Plato also discussed introduction of changes in the political system and innovations in music, but in a negative context:

"Let us say briefly, that this is what state administrators should follow: preventing the change of a state without their knowledge, above all not to allow introduction of innovations in the gymnastics and music education, since it needs to maintain the same. Thus when someone says that people listen most attentively to the song 'which, when they are singing, sounds completely new to them' they should be afraid and especially careful, lest anyone thought, that the poet is not singing new songs but the new manner of a song, and lest anyone praise that. And this should not be praised nor received. Because one needs to be careful and avoid making new music, regarding that it is jeopardy for everyone. Namely, if musical laws change anywhere, the biggest laws of the state will change as well..." (Platon, 1997, 424b4-c6).

In his works Gozze treated harmony from several different aspects. First, in the context of defining beauty Gozze interpreted harmony in general as coherency of constituent parts of an object, thus in the case of music that meant the interrelationship between the constituent parts of music, i.e. sounds:

“...the ear itself does not enjoy anything as much as the musical harmony [l'armonia della Musica]. Just as the noise, carrying fear in itself, prompts cowards to escape, so the harmony of sounds [suoni armonici] moves our souls towards the pleasure of beauty" (Gučetić, 1995, 83-85).

Secondly, in the context of Pythagorean concept of harmony of numbers, Gozze made an analogy between musical harmony and the mathematical order of the universe:

"Because of that we should believe that the art of music came down from the choir of blissful angels, since the sound of music captivates our soul more with divine, than with earthly beauty: thus Plato believes that our soul consists of certain harmony of numbers [numeri armonici]; hence he says well in his dialogue Sophist, that our life seeks certain accordance of numbers [numerosa consonanza] and that studying of music should be placed above all other studies." (Gučetić, 1995, 83-85).

Thirdly, Gozze believes that harmony is also very important constituent part of music within educational system:

"For education of the children and their learning our Philosopher suggests four well known subjects, and those are: literature, gymnastics, music and painting. 
(...) ...music includes harmony, vocal as well as instrumental [soto la Musica, l’armonia cosi vocale, comi ogne sorte d'istrumeti]." (Gučetić, 2000, 407).

Finally, in Gozze's opinion harmony is the element of music which has strong influence on human emotions and a positive effect on human health:

"Musical harmony can actually calm down and touch human soul, which is proved by the example of Pythagoras's pupil Alexander the Great, as well as Gaius Gracchus, whose passions it constrained and eased.” (Gučetić, 2000, 414).

"And if harmony saved the Romans from the deadly plague, when satires were sung for recovery, why shouldn't we heal our souls, too, with its help, if the soul has always been considered more divine than human and if the bodily accord and harmony are maintained by the harmony of spiritual powers and passions?" (Gučetić, 2000, 414-415).

In Gozze's writings on music it is the category of rhythm that is least elaborated and practically neglected since Gozze mentioned it shortly only in his discussion on musical instruments. We can only speculate about his reasons for not analysing rhythm in more detail. Thus it is possible to assume that Gozze simply did not regard rhythm as a separate element of music which can be isolated from other categories, i.e. modes and harmony, and perhaps he considered it only as a part of music as a whole (Gučetić, 2000, 414).

\section{3) The Functions and effects of music: paideia and leisure}

When writing about functions and effects of music Gozze always puts it into the same context - the paideia. As is well known, the notion of paideia in ancient Greece referred not only to education and learning, but also to the totality of the cultural and ethical experience. Thus, the formal process of learning in its meaning today should be understood only as its initial stage (Mathiesen, 2001). Paideia was also closely related to the theory of ethos, a concept that connected music and education in a particular way (Anderson and Mathiesen, 2001). The belief in its special powers for developing good or evil in man consequently produced the idea of submiting music to strict control.

Gozze's discussion on paideia and music education actually represents a certain critique of contemporary society in Dubrovnik that apparently lived extravagantly and neglected education of children (Perić, 1964, 18-36). In his works Gozze on several occasions expressed his discontent with the attitude of his fellow citizens towards education (e.g. Gučetić, 1998, 67, 215; Gučetić 2000, 126-127). In his later works Gozze approached the issue of music primarily from the standpoint of a practical politician. However, even within the context of 
treating the manners of governing a city, he sets music apart as having a special importance in education and learning. Gozze also advocates the establishment of the best among political systems, considering that this system could be maintained only by avoiding any subsequent changes, and he explains his attitude by drawing an analogy between political systems and musical concords (Gučetić, 2000, 194). Gozze's negative attitude towards innovations and his insisting on the needs of equal education and learning could be traced back to Plato (Jurić, 2011, 38-39). He considered education and learning to be directed always towards the benefits of the state, and not to anybody's personal advantage. Plato insisted that changes and innovations should be avoided within educational system and music (Platon, 1997, 424b4-c6).

Unlike Plato, who in his discussion on music wanted to repress individual inclinations in the context of paideia in order to achieve uniformed homogeneous society, Gozze on several occasions in his works pointed out the importance of individual inclinations within the educational process:

“...in order to learn virtue we need benevolence of nature, because everything we learn through receiving, we learn according to nature; our bodies differ from the wild animals, thus our souls are different from theirs, and also our natural aspirations and inclinations towards sciences and humanities will be different, and by that natural inclinations we differ among ourselves, since everyone is given distinct structure. Proper activity needs practice, which has such strength that it can resist nature itself (...) Our nature often guides us towards good or evil act, but habit and firm custom deflect it in one direction or in the other. (...) Habit always shows its power among people, for its natural strength is expressed among unreasonable creatures who do not listen much to reason, but when they are guided by reason and discipline they become obedient among people." (Gučetić, 2000, 393).

Gozze almost regularly mentions the term inclination along with the term habit, for he thought that only through consistent practice of certain habits it was possible to repress possible negative inclinations, and also to develop the abilities enabled by positive innate inclinations.

Gozze took over from Aristotle the notion of music as a multifunctional phenomenon, pointing out that music has other purposes besides paideia, and those are rest, entertainment and pleasure. In this context Gozze also discussed the Aristotelian term leisure:

"...I am not following the opinion of ancient [authors] who thought it [music] is essential to children for development of hearing, nor the ones who thought it was necessary for habituation of the mind, so that due to harmony it recognizes concordance among things, thus they wanted to strengthen a soul of a child through harmony of singing and playing of instruments. I am following ... the 
idea of our Philosopher [i.e. Aristotle], believing that music should preoccupy our souls in a kind and pleasant manner in tranquillity and leisure time, having a beneficial power to fulfil leisure time when we are not obliged to take care of important issues. Thus, in order to be able to live in a praiseworthy way [...] children should also be taught the art of music, which was not included in the liberal arts without reason by ancient philosophers, because it helps us to spend leisure time in a correct and non-contaminated way. But, along with being indispensable it is also manifoldly appropriate, because it offers by its nature great embellishment to governing and benefit to the state of mind, as music by its influence incites various emotions in souls..." (Gučetić, 2000, 407-408).

Gozze considers that the most important function of music lays within leisure, and places his platonic attitude, i.e. the function of music in the process of creating proper habits, at a somewhat lower level. It is interesting to note that Gozze also mentioned leisure time in a negative context, arguing it is the greatest enemy of paideia, being thus its contrast. Gozze considers leisure and paideia as two complete separated fields - the first one intended only for adults, and the second one for childhood - but Gozze also believes that engaging in musical activities within educational system is an important precondition for musical activities a person will engage in during its maturity (cf. Gučetić, 1998, 91, 235).

In his earliest printed work, Dialogo della bellezza (1581), Gozze treated music in a somewhat different manner than in his later works. In this work music is primarily presented as one of the ways by which the soul is raised towards beauty, although already in this work the background would point to music education, too. In this work we can also perceive elements of music education, in the passage Gozze discusses what we would call today "the female or feminist issue", for Gozze explicitly puts the question whether it is at all permissible for women to be taught music. This topic logically followed from the discussion on the Aristotelian idea of music as pleasure and entertainment, according to which dealing with music was inconsistent with the honesty of women:

"... I would only like to tell you that there was some disagreement between the Platonists and some Peripathetics on the issue of whether a woman or a girl be allowed to know music; those Peripathetics were saying that it was not allowed, because music and honesty rarely matched together, being enemies. But Platonists and true Peripathetics were thinking in a different way, i.e. that music was suitable to a beautiful woman, and that was well shown by Agostino Sessa, who - following Aristotle, the king of the Peripathetic teaching, who in the eighth chapter of his Politics, wanting to teach the civilized man music, poetry, painting and military skills - said that for noble men, since they spend most of their lives in honest leisure time, the above-mentioned skills are necessary at large; thus for all honest women, who [also] spend most of their lives in honest leisure time, the art of music would be even more suitable." (Gučetić, 1995, 113115). 
In this short passage Gozze touched upon the issue of the position of women in [Dubrovnik] society, offering a modern attitude in advocating women to be permitted to deal with music.

\section{Conclusion}

From the analysis of the three works by Niccolò Vito di Gozze it is apparent that his thoughts on music were influenced primarily by Plato and Aristotle. That influence is evident in his discussion on musical instruments, where Gozze listed old instruments, and especially in his attitude on wind instruments as inappropriate for noblemen. Regarding Gozze's musico-theoretical ideas, he described several examples from the Greek mythology which illustrate impact of different musical modes on human behaviour and moods. The influence of ancient Greek philosophers is best proved by the fact that Gozze discussed music within the context of paideia, which also represents the most important part of Gozze's thoughts on music, whereby he created a kind of a compound of Plato's and Aristotle's ideas about music. On the one hand Gozze accepted Plato's idea of uniformity of paideia and points out that music is the essential part of educational system, but unlike Plato he thinks that within the educational process special attention should be dedicated to individual inclinations. On the other hand Gozze distanced himself from Plato by accepting Aristotle's notion of music as a multifunctional phenomenon which fulfils an important function outside of paideia. In comparison to Aristotle Gozze also brought in a new feature, since he discussed possible negative ways in which leisure could influence the paideia.

Considering Gozze's socio-political engagement, the especially important part of his discussion on music represents his introduction of practical dimension. Namely, in each topic Gozze discussed he took a step further then his ancient Greek ideals, bringing in his ideas on music consideration of concrete contemporary situation in the field of music, thus shaping his own attitude about music in accordance with the spirit of his time.

\section{References}

Anderson, W. and Mathiesen, T. J., 2001. Ethos. In: S Sadie, ed. NGroveD. 8. London: OUP, 403-407.

Aristotel, 1992. Politika. Translated by T. Ladan. Zagreb: Hrvatska sveučilišna naklada. Castiglione, B., 1986. Dvoranin. Translated by F. Čale. Zagreb: Cekade.

Demović, M., 1981. Glazba i glazbenici u Dubrovačkoj republici: od početka 11. do polovine 17. stoljeća. Zagreb: JAZU. 
Gučetić, N. V., 1581. Dijalog o ljepoti - Dijalog o ljubavi. [Dialogo della bellezza Dialogo d'amore]. Translated by N. Badurina. 1995. Zagreb: Tiskara Puljko.

Gučetić, N. V., 1591. O ustroju država. [Dello stato delle republiche] Translated by N. Badurina and S. Husić. 2000. Zagreb: Golden marketing.

Gučetić, N. V., 1589. Upravljanje obitelji. [Governo della famiglia]. Translated by M. Zaninović. 1998. Zagreb: Hrvatski studiji - Studia Croatica.

Jurić, M., 2011. Ethos i paideia u Platonovim i Aristotelovim promišljanjima o glazbi. Arti musices, 42/1, 37-54.

Jurić, M., 2012. Paideia i neoplatonističke ideje o glazbenom odgoju i kulturi u renesansnom Dubrovniku u djelima Nikole Vitova Gučetića (1549-1610). Arti musices, 43/2, 175-188.

Mathiesen, T. J., 2001. Paideia. In: S Sadie, ed. NGroveD, 18. London: OUP. 899900.

Munrow, D. 1976. Instruments of the Middle Ages and Renaissance. London: OUP. Perić, I., 1964. Pedagoški pogledi Nikole Gučetića. Dubrovnik, 7/1, 18-36.

Platon, 1997. Država. Translated by M. Kuzmić. Zagreb: Naklada Jurčić.

Tuksar, S., 1992. Hrvatska glazbena terminologija u razdoblju baroka: nazivlje glazbala $i$ instrumentalne glazbe u tiskanim rječnicima izmedu 1649. $i 1742$. godine. Zagreb: HMD.

Tuksar, S., 2004. Glazba, akademije i učena društva djelatna u hrvatskim zemljama u razdoblju od 16. do 18. stoljeća. Arti musices, 35/1, 3-19. 